\title{
Enhanced Anti-Cancer Effect of Folate-Conjugated Olaparib Nanoparticles Combined with Radiotherapy in Cervical Carcinoma
}

This article was published in the following Dove Press journal: International Journal of Nanomedicine

\author{
Dong $\mathrm{Li}^{1, *}$ \\ Chuanfei Hu${ }^{\mathrm{l}, *}$ \\ Juan Yang' \\ Yin Liao (D) \\ Yue Chen ${ }^{2,3}$ \\ Shao Zhi Fu (D) \\ Jing Bo $\mathrm{Wu}^{\mathrm{l}, 3}$
}

'Department of Oncology, The Affiliated Hospital of Southwest Medical University, Luzhou 646000, People's Republic of China; ${ }^{2}$ Department of Nuclear Medicine, The Affiliated Hospital of Southwest Medical University, Luzhou 646000, People's Republic of China; ${ }^{3}$ Nuclear Medicine and Molecular Imaging Key Laboratory of Sichuan Province, The Affiliated Hospital of Southwest Medical University, Luzhou 646000, People's Republic of China

*These authors contributed equally to this work
Correspondence: Jing Bo $\mathrm{Wu}$

Department of Oncology, The Affiliated Hospital of Southwest Medical University, No. 25, Taiping Street, Luzhou 646000,

People's Republic of China

Emailwjb6|47@I63.com

Shao Zhi Fu

Department of Oncology, The Affiliated Hospital of Southwest Medical University,

No. 25, Taiping Street, Luzhou 646000,

People's Republic of China

Tel +868303165698

Fax +868303165690

Email shaozhifu5I3@I63.com
Background: Radiotherapy (RT), one of the main treatments for cervical cancer, has tremendous potential for improvement in the efficacy. Poly (ADP-ribose) polymerase (PARP) is a key enzyme in the repair of DNA strand breaks (DSB). Olaparib (Ola) is a PARP inhibitor that is involved in preventing the release of PARP from RT-induced damaged DNA to potentiate the effect of RT. Although the basic mechanism of Ola's radiosensitization is well known, the radiosensitization mechanism of its nanomedicine is still unclear. In addition, the lack of tumor tissue targeting is a major obstacle for the clinical success of Ola.

Materials and Methods: In this study, we developed folate-conjugated active targeting olaparib nanoparticles (ATO) and investigated the anti-tumor effect of ATO combined with radiotherapy (RT) in nude mice using cervical cancer xenograft models. We used folate (FA)conjugated poly ( $\varepsilon$-caprolactone)-poly (ethyleneglycol)-poly (e-caprolactone) (PCEC) copolymer to prepare ATO via emulsification/solvent diffusion. Further, we evaluated ATO particle size, potential, encapsulation efficiency, and in vitro release characteristics, and evaluated the shape of ATO via transmission electron microscopy (TEM). We then performed MTT and cell uptake assays to detect cytotoxicity and targeting uptake in vitro. We investigated the anti-tumor properties of ATO in vivo by apoptosis test, 18 F-FDG PET/CT, and immunohistochemical analysis. Finally, the xenografted tumor in nude mice was subjected to RT and/or ATO treatment.

Results: The results confirmed that ATO in combination with RT significantly inhibited tumor growth and prolonged survival time of tumor-bearing mice. This may be related to the inhibition of tumor proliferation and DNA damage repair and induction of cell apoptosis in vivo.

Conclusion: The ATO developed in this study may represent a novel formulation for olaparib delivery and have promising potential for treating tumors with an over-expression of folate receptors.

Keywords: olaparib, cervical cancer, folate, anti-cancer effect, active targeting

\section{Introduction}

Cervical cancer is one of the most common cancers in women worldwide, ${ }^{1}$ and RT is the main treatment for advanced cervical cancer. However, not so many effective methods to improve the efficacy of RT currently exist. Although cisplatin is traditionally widely used in combination with RT, it has severe side effects in patients. Therefore, exploring new approaches to improve the efficacy of RT has important clinical value. Research suggests that the mechanism of killing tumor 
cells by RT involves DNA strand breaks (DSBs). ${ }^{2}$ Poly (ADP-ribose) polymerase (PARP) is a key enzyme for DNA repair, and PARP inhibitors can selectively inhibit PARP activity, thereby inhibiting DNA strand repair and forming a large number of broken single-stranded DNAs, which eventually cause the double-stranded DNA to break at the replication fork and improves the efficiency of RT. $^{3-5}$ Olaparib (Ola) is a well-known highly selective PARP inhibitor. Although current studies about the antitumor effects of Ola combined with RT in vitro are relatively detailed, there are few studies regarding this in vivo; thus, further research needs to be conducted. ${ }^{6-8}$ Nevertheless, with the lack of tumor tissue targeting, Ola use clinically leads to common adverse reactions such as anemia, nausea, and vomiting. ${ }^{9}$ In addition, issues such as poor water solubility, high toxicity, and poor stability have largely prevented the popularization and application of Ola in clinical use. In recent years, there are many studies about nano-delivery system for cancer therapy, which can enhance the efficacy and targeting of drugs. ${ }^{10-12}$ Therefore, developing a targeted nano-delivery system capable of solving the abovementioned issues is important.

Folate receptors have recently been confirmed to be over-expressed on the surfaces of some tumor cells such as those of cervical cancer, ovarian cancer, and nasopharyngeal cancer. ${ }^{13}$ The differential expression of folate receptors in tumor tissues and normal tissues makes them ideal targets for targeted drug delivery. ${ }^{14}$ Therefore, a new folate-conjugated nano-drug delivery system capable of targeting the folate receptor has emerged, which is considered to be a promising anti-cancer drug carrier, thus providing a feasible solution to the abovementioned problems. ${ }^{15,16}$ Our previous study had shown that Ola nanoparticles can enhance the radiosensitivity of lung cancer xenografts in nude mice. ${ }^{17}$ Furthermore, folateconjugated honokiol nanoparticles show active-targeted inhibitory effect on nasopharyngeal carcinoma xenografts enriched with folate receptors on the cell surface. ${ }^{18}$ Therefore, in this study, we prepared folate-conjugated Ola nanoparticles that actively targeted folate receptors.

A large number of studies have reported anti-tumor effects of Ola combined with RT, including details on the drug and radiation doses. ${ }^{5,17}$ Thus, an optimal drug dose of Ola (50 mg/kg/d, 3 days) and radiation dose (10 Gy) were used for subsequent experiments. The purpose of this study was to prepare ATO and study the anti-tumor effects of ATO in combination with RT on cervical carcinoma subcutaneous xenograft model.

\section{Materials and Methods}

\section{Materials}

Ola with a purity level of $99.8 \%$ was purchased from Meilun Co., Ltd (Dalian, China). $\varepsilon$-Caprolactone ( $\varepsilon-\mathrm{CL})$, poly (ethylene glycol) (PEG, $\mathrm{Mn}=4000$ ), and stannous octoate $\left(\mathrm{Sn}(\mathrm{Oct})_{2}\right)$ were purchased from Sigma-Aldrich (St. Louis, MO, USA). Dicyclohexylcarbodiimide (DCC), N-hydroxysuccinimide (NHS), N,N'Diisopropylcarbodiimide (DIC), MTT, and fluorescein isothiocyanate (FITC) were purchased from SigmaAldrich. Further, dimethyl sulfoxide (DMSO), folate, petroleum ether, anhydrous ethanol, acetonitrile, and methanol (HPLC grade) were purchased from KeLong Co., Ltd (Chengdu, China). Tetrahydrofuran (THF) was purchased from Bioway (New York, NY). $\gamma$-H2AX, Ki67, and CD-31 polyclonal antibodies were purchased from Bioworld Technology Co., Ltd (Nanjing, China).

Hela and A549 cell lines were provided by Zhongke Quality Inspection Biotechnology Co., Ltd (Beijing, China). BALB/c mice (female, nu/nu, 4-5 weeks old) were purchased from Chongqing TengXin biotechnology Co., Ltd (Chongqing, China).

\section{Synthesis of Folate-Conjugated PCEC (FA-PCEC)}

The synthesis route of FA-PCEC is shown in Figure 1. First, PCEC was synthesized from polyethylene glycol and $\varepsilon$-CL via ring-opening polymerization using $\mathrm{Sn}(\mathrm{Oct})_{2}$ as a catalyst, as reported previously. ${ }^{19} \mathrm{Next}$, the target polymer FA-PCEC was synthesized in three steps. ${ }^{20,21}$ BocL-Phe-terminated PCEC was obtained as follows: a nitrogen-purged flask containing $10 \mathrm{~g}$ of PCEC and 3.1 $\mathrm{g}$ of Boc-L-Phe, dissolved in $80 \mathrm{~mL}$ anhydrous dichloromethane, was cooled to $-10^{\circ} \mathrm{C}$. The mixture was then poured into a solution containing $0.8 \mathrm{~g}$ of DCC and 0.08 $\mathrm{g}$ of DAMP and incubated for $48 \mathrm{~h}$ at $0^{\circ} \mathrm{C}$. Second, $6 \mathrm{~g}$ of Boc-L-Phe end-capped PCEC was added to $70 \mathrm{~mL}$ dry methylene dichloride; the mixture was then cooled to $0^{\circ} \mathrm{C}$. Following this, $15 \mathrm{~mL}$ trifluoroacetic acid was added to the solution under nitrogen atmosphere for $2 \mathrm{~h}$. Aminoterminated PCEC was obtained by vacuum drying at room temperature for $48 \mathrm{~h}$. Finally, $806.4 \mathrm{mg}$ of aminoterminated PCEC was dissolved in $60 \mathrm{~mL}$ DMSO, and mixed with $440 \mathrm{mg}$ of folate. Subsequently, $253 \mathrm{mg}$ of DIC and $230 \mathrm{mg}$ of NHS were added to the solution as catalysts. The reaction was performed at $37^{\circ} \mathrm{C}$ for $24 \mathrm{~h}$; the supernatant was collected, dialyzed for $72 \mathrm{~h}$, and dried in 

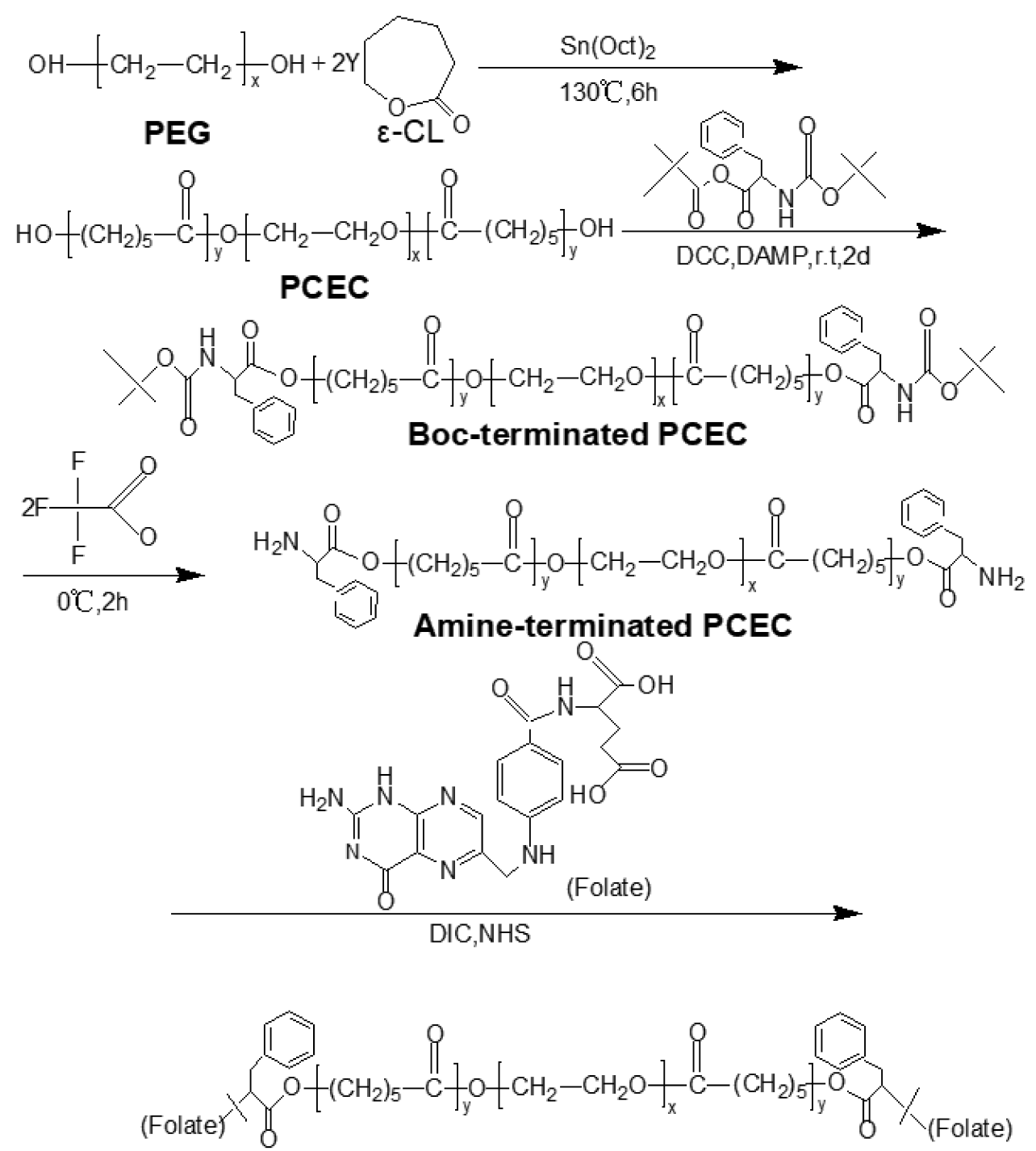

FA-PCEC

Figure I The synthesis route of FA-PCEC block copolymer.

Abbreviation: PEG, polyethylene glycol.

a freeze dryer to obtain FA-PCEC. A proton NMR spectrometer was used to detect the characteristic peaks of protons to verify whether folate was attached to PCEC.

\section{Preparation of ATO}

ATO was prepared by emulsification/solvent diffusion method. $^{22,23}$ Ola $(4 \mathrm{mg}$ ) and FA-PCEC copolymer (46 mg) were dissolved in $2 \mathrm{~mL}$ DMSO to induce a diffusing phase; the solution was then added to $10 \mathrm{~mL}$ dispersing phase (PVA $0.5 \%$ in water) that was under a magnetic stirrer $(300 \mathrm{rpm}, 10 \mathrm{~min})$ using a syringe. The nanoparticles were obtained by dialyzing against water for $48 \mathrm{~h}$ to remove DMSO and free Ola. A sterile filter with a $220-\mathrm{nm}$ pore size was used to filter the suspension. The nanoparticles were then centrifuged at 20,000 $\mathrm{g}$ for $15 \mathrm{~min}$, followed by several washing steps with distilled water. The orange-colored active targeting nanoparticles were then freeze-dried and stored at $4{ }^{\circ} \mathrm{C}$. Non-active targeting olaparib nanoparticles (NATO), which were not modified with folate, were prepared by a similar method, with the replacement of FA-PCEC copolymer with PCEC copolymer.

\section{Characterization of ATO}

The size distribution and Zeta potential of ATO were measured by dynamic light scattering (DLS, NanoBrook90 plus Zeta, Brookhaven, USA) at $25^{\circ} \mathrm{C}$. All results were averages of three test runs. The structure of ATO was determined 
using a transmission electron microscope (TEM, Tecnai G2 F20, USA).

\section{Drug Loading (DL) and Encapsulation Efficiency (EE)}

The DL and EE of ATO were determined via highperformance liquid chromatography (HPLC, Agilent, Richardson, TX), and chromatographic analysis was performed using a reversed-phase $\mathrm{C} 18$ column $(4.6 \times$ $150 \mathrm{~mm}, 5 \mu \mathrm{m}$, USA) as per a previously reported method. ${ }^{24}$ The specific steps are as follows. ATO was dissolved in the mobile phase, which contained acetonitrile/water $(64 / 36, v / v)$. The air from mobile phase was exhausted $30 \mathrm{~min}$ before use, and the mobile phase was applied with a flow rate of $1.0 \mathrm{~mL} / \mathrm{min}$ through the column at $25^{\circ} \mathrm{C}$. The volume of each injection was $20 \mu \mathrm{L}$, and the detection wavelength was set at $276 \mathrm{~nm}$. DL and EE were calculated according to the following formula:

$\mathrm{DL}=$ Olaparib/Olaparib+Polymer

$\mathrm{EE}=$ Actual DL/Theoretical DL

\section{In vitro Drug Release of Ola and ATO}

The release of Ola from ATO in vitro was evaluated as follows: $1 \mathrm{mg}$ Ola or ATO containing $1 \mathrm{mg}$ Ola (theoretical DL, $8 \%$ ) were separately dissolved in $1 \mathrm{~mL} \mathrm{DMSO}(1 \mathrm{mg} / \mathrm{mL})$ and $1 \mathrm{~mL}$ distilled water $(1 \mathrm{mg} / \mathrm{mL})$, and then separately poured into corresponding sealed dialysis bags (molecular weight cutoff, $3.5 \mathrm{kDa}$ ). The bags were individually incubated at $37^{\circ} \mathrm{C}$ in $30 \mathrm{~mL}$ PBS $(\mathrm{pH}=7.4)$, containing Tween- 80 $(0.5 \%, \mathrm{w} / \mathrm{w})$, with gentle stirring $(100 \mathrm{rpm})$. The incubation medium was replaced with the same volume $(2 \mathrm{~mL})$ of freshly preheated medium $\left(37^{\circ} \mathrm{C}\right)$ at predetermined time points. Subsequently, the collected release drug was centrifuged at $12,000 \mathrm{rpm}$ for $15 \mathrm{~min}$ at $4^{\circ} \mathrm{C}$. Following this, $1 \mathrm{~mL}$ of supernatant from each group was collected and stored at $-20^{\circ} \mathrm{C}$ for further analysis. All supernatant samples were analyzed via HPLC and experiments were performed at least in triplicates.

\section{Cytotoxicity Assay and Cellular Uptake of Nanoparticles}

The cytotoxicity was evaluated via MTT assay. In brief, Hela cells were seeded in 96 -well plates at a density of $5 \times$ $10^{3}$ cells/well and incubated for $24 \mathrm{~h}$ at $37^{\circ} \mathrm{C}$; the cells were then exposed to free Ola, NATO, and ATO at different concentrations ( 0 to $5 \mathrm{nmol} / \mathrm{L}$ ) for $24 \mathrm{~h}$. Subsequently, 10 $\mu \mathrm{L}$ of MTT solution was added to the cells, and cell viability was analyzed after incubation for $4 \mathrm{~h}$ by dissolving the formazan precipitate in DMSO and recording the absorbance at $490 \mathrm{~nm}$ using a microplate reader (iMark, BioRAD, USA).

FITC-labeled PCEC nanoparticles and FA-PCEC nanoparticles were prepared as described previously. ${ }^{25}$ An ethanol solution of FITC was added to $1.0 \mathrm{mg} / \mathrm{mL}$ of PCEC or FA-PCEC nanoparticle solution, and the FA-PCEC nanoparticles to FITC molar ratio was controlled at 1:4. The solution was stirred $(400 \mathrm{rpm})$ for $24 \mathrm{~h}$ at room temperature in a dark environment. The reaction product was then dialyzed against deionized water for $24 \mathrm{~h}$ using a dialysis membrane (MWCO: $3.5 \mathrm{kDa}$ ) to remove un-reacted FITC. HeLa cells and A549 cells were then seeded at a concentration of $1 \times 10^{5}$ cells/well in a 6-well plate and incubated for $24 \mathrm{~h}$. Following this, $50 \mu \mathrm{L}$ of medium containing $10 \mu \mathrm{g} / \mathrm{mL}$ FITC-PCEC nanoparticles was added to the 6-well plate with Hela cells and incubated for $6 \mathrm{~h}$. The FITC-FA-PCEC nanoparticles were added to a separate 6-well plate with Hela cells and A549 cells. For comparison, free FA dissolved in DMSO was added to a fresh medium containing FITC-FA-PCEC nanoparticles at a concentration of $10 \mu \mathrm{g} / \mathrm{mL}$ and poured into a 6-well plate with Hela cells. After washing the cells three times with PBS $(0.01 \mathrm{M}, \mathrm{pH}=7.4)$, they were observed under a fluorescence microscope (Olympus, Tokyo, Japan).

\section{In vivo Evaluation of Anti-Tumor Efficacy}

Animal experiments were performed according to Guidelines for the Feeding, Management and Use of Laboratory Animals and were approved by the Institutional Animal Care and Treatment Committee of Southwest Medical University (Luzhou, China). In brief, the tumor xenograft model was established by subcutaneously injecting Hela cells $\left(1 \times 10^{6}\right.$ cells in $100 \mu \mathrm{L}$ PBS $)$ into the right thigh of athymic $\mathrm{BALB} / \mathrm{c}$ nude mice (female, 4-5 weeks old). When the average volume of the subcutaneous tumor reached $150-200 \mathrm{~mm}^{3}(\mathrm{~V}=\mathrm{a} \times \mathrm{b} 2 / 2$, where $\mathrm{a}$ and $\mathrm{b}$ are the longest and shortest diameters of the tumor, respectively), the mice were randomly divided into six groups as follows ( $\mathrm{n}=12$ per group): Control ( $0.9 \%$ normal saline [NS]); NATO; ATO; RT (a single dose of $10 \mathrm{~Gy}$ ); NATO+RT; and ATO+RT. Subsequently, each mouse in the drug-treated group was intravenously administered $50 \mathrm{mg}$ / $\mathrm{kg}$ of Ola standard for 3 days. RT was only conducted 30 min after the first drug administration. The long and short diameters of the tumor were measured every 2 days from the first day of drug administration using a Vernier caliper, and the tumor volume was calculated based on the tumor 
volume calculation formula described before. The measurement was stopped after the tumor volume reached four times the initial tumor volume. The tumor growth delay (TGD) was calculated by Ti4 - T4, where Ti4 is the time taken for the tumor volume to reach four times the initial tumor volume after treatment and $\mathrm{T} 4$ is the time taken for the control tumor volume to reach four times the initial tumor volume. On day 10 after drug administration, mice from each group were selected and dissected to resect the heart, liver, spleen, lung, and kidney for H\&E staining for evaluating drug toxicity. The remaining mice in each group were used to observe median survival.

Small animal PET/CT was performed to explore therapy response and early metabolism of tumor tissue with different treatments. The mice were randomly selected from each group for the scan and were not allowed to drink or eat for at least $8 \mathrm{~h}$ before the scan. The mice were then anesthetized with $1 \%$ pentobarbital $(5 \mathrm{mg} / \mathrm{kg})$ intraperitoneal injection and injected with $100-200 \mu \mathrm{Ci}$ FDG $(0.1 \mathrm{~mL})$ in the tail vein. PET/CT scan imaging was performed at least $30 \mathrm{~min}$ after the intravenous injection. The parameters were as follows: voltage, $80 \mathrm{kV}$; current, $500 \mu \mathrm{A}$; section thickness, $1.5 \mathrm{~mm}$, and $10 \mathrm{~min}$ per bed position.

\section{Immunohistochemical Analysis}

Within $48 \mathrm{~h}$ after the first administration, three nude mice were randomly selected from each group to obtain tumor tissues for immunohistochemical detection of $\gamma-\mathrm{H} 2 \mathrm{AX}$. Further, 10 days after drug administration, the obtained tumor tissue was used for the detection of other immunohistochemical indicators such as Ki-67. Specific steps are as follows: the tumor tissue was fixed in $10 \%$ neutral formaldehyde for at least $24 \mathrm{~h}$, it was then embedded in paraffin and cut into 3-4- $\mu$ m-thick sections and stained with H\&E for immunohistochemical analysis. The detailed procedures for $\gamma-\mathrm{H} 2 \mathrm{AX}$ and $\mathrm{Ki}-67$ expression detection were according to the manufacturer's instructions (Bioworld Technology, Nanjing, China) and pictures were taken using an optical microscope (Olympus, Tokyo, Japan). The expression levels of $\gamma$-H2AX and Ki67 were calculated at three randomly selected areas in each tumor sample at $200 \times$ magnification as the number of positive cells/total number of cells.

\section{Apoptosis Analysis}

Ten days after drug administration, the obtained tumor tissue was used for apoptosis analysis. Cellular apoptosis was analyzed by flow cytometry (BD FACSVerse, Piscataway,
NJ). The tumor tissue was shredded and added to $2 \mathrm{~mL}$ trypsinization buffer placed in a $37^{\circ} \mathrm{C}$ incubator with gentle shaking to digest. After $40 \mathrm{~min}$ of digestion, the serumcontaining medium was added to stop the digestion. Following this, the mixture was filtered using a nylon gauze of pore size $70 \mu \mathrm{m}$ to remove the undigested tumor tissue. The collected cell suspension was centrifuged at $1000 \mathrm{rpm}$ for $2 \mathrm{~min}$ and washed twice with physiological saline. Subsequently, $5 \mu \mathrm{L}$ of propidium iodide and $5 \mu \mathrm{L}$ of fluorescein isothiocyanate were added to each test tube. Cells were incubated at room temperature in the dark for $15 \mathrm{~min}$, and $400 \mu \mathrm{L}$ of pre-cold $1 \times$ binding buffer was then added. After gentle mixing, the cell suspensions were analyzed via flow cytometry (BD FACSVerse, Piscataway, NJ).

\section{Statistical Analysis}

Data analysis was processed by SPSS 18.0 software using $t$-test for two-group comparisons and one-way ANOVA for comparisons of more than two groups. The value obtained is expressed as mean \pm standard deviation $(\mathrm{x} \pm \mathrm{s}) . P<0.05$ was considered statistically significant.

\section{Results}

\section{Characterization of FA-PCEC Copolymer} In this study, we successfully synthesized FA-PCEC copolymer. The structure of the FA-PCEC copolymer was detected via nuclear magnetic resonance hydrogen spectroscopy. As shown in Figure 2, the copolymer shows characteristic PCL peaks at $1.4 \mathrm{ppm}, 1.6 \mathrm{ppm}, 2.3 \mathrm{ppm}$, and $4.1 \mathrm{ppm}$ and a typical PEG characteristic peak at $3.5 \mathrm{ppm}$. The characteristic peaks of PCL and PEG appeared in the same position in the NMR hydrogen spectrum for both PCEC and FA-PCEC, but the typical peaks of folate were seen in FA-PCEC at $6.6 \mathrm{ppm}, 7.6 \mathrm{ppm}$, and $8.6 \mathrm{ppm}$. Based on this analysis, it can be concluded that folate was successfully branched on PCEC and the target polymer FA-PCEC was successfully synthesized.

\section{In vitro Characterization of ATO}

The particle size and morphology of ATO were detected by DLS and TEM. The average hydrodynamic diameter of ATO was $240.62 \pm 8.79 \mathrm{~nm}$ (Figure 3A), furthermore, the zeta potential of ATO was $-10.5 \pm 1.09 \mathrm{mV}$ (Figure 3C). As a comparison, the average hydrodynamic diameter of ATO was $205.43 \pm 3.13 \mathrm{~nm}$ (Figure 3B), the zeta potential of ATO was $4.67 \pm 1.17 \mathrm{mV}$ (Figure 3D). The obtained ATO was mono-dispersed and stabilized in an aqueous 


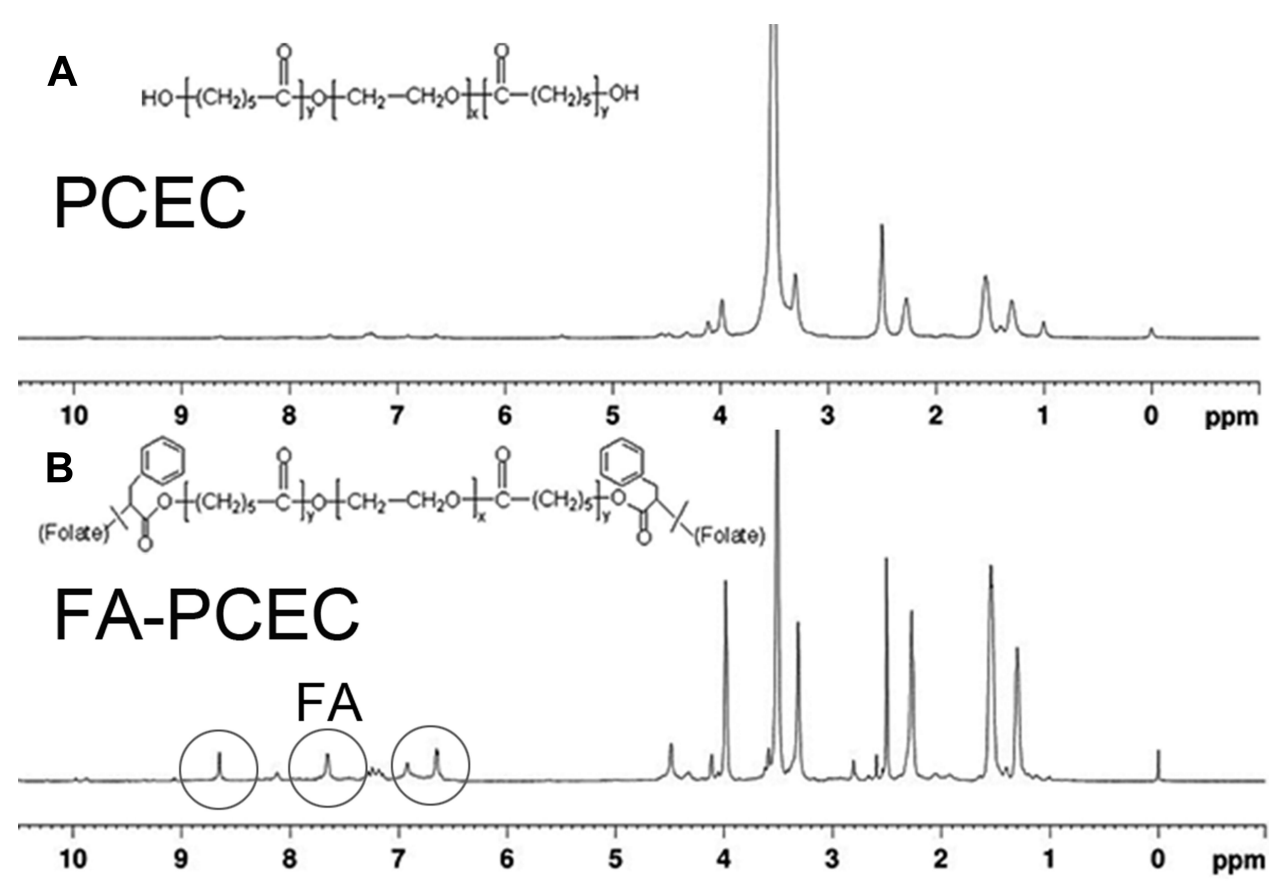

Figure 2 H-NMR spectra of PCEC (A) and FA-PCEC (B). The gray circle represents the characteristic peak of FA. Abbreviation: H-NMR, NMR hydrogen spectroscopy.

solution; the appearance of ATO was spherical as shown in the TEM image (Figure 3E).

As mentioned before, the theoretical DL of ATO was set at $8 \%$. However, HPLC results showed that the actual DL and EE of ATO were $6.44 \% \pm 0.05 \%$ and $80.54 \pm$ $0.63 \%$, respectively. As shown in Figure $3 \mathrm{~F}$, in vitro release of free Ola showed a rapid release trend and approximately $90 \%$ of Ola was released into the medium within 4 days. In contrast, ATO showed a slow and longlasting release trend, and $80 \%$ of Ola was released from ATO within 10 days.

\section{Cytotoxicity Assay and Cellular Uptake}

To evaluate the cytotoxicity of ATO, MTT assay was performed using HeLa cells. The dose-dependent inhibitory effect of free Ola, NATO, and ATO on Hela cells is illustrated in Figure 4A. The cytotoxicity of ATO was superior to that of free Ola basically. Moreover, compared with free Ola and NATO, ATO showed a stronger inhibitory effect when the concentration was $200 \mu \mathrm{g} / \mathrm{L}$. When the concentration was $200 \mu \mathrm{g} / \mathrm{L}$, the viability of cells treated with ATO was $53.2 \pm 1.5 \%$, which was significantly lower than that of cells treated with NATO and treated with NATO, indicating that the therapeutic effect of Ola was enhanced when Ola was incorporated into nanoparticles to form ATO. Figure 4B illustrates the cytotoxic effect of FA-PCEC on HeLa cells. No cytotoxicity was detected among all the tested concentrations, indicating that the anti-tumor activity of ATOs was attributed to Ola, which released from the nanoparticles. This indicated that FA-PCEC copolymer has good cytocompatibility and can be considered a safe drug delivery vehicle.

To verify the targeting ability of ATO, cell uptake experiments were conducted in Hela cells and A549 cells. Because A549 cells do not have folate receptors, thus A549 cells were chosen as negative control group. Fluorescence images obtained after incubation with FITC-labeled NATO and ATO are shown in Figure 4C. In Hela cells, no fluorescence spot was observed in the Control group, and fluorescence intensity of FITC-labeled ATO was more pronounced than that of FITC-labeled NATO, indicating that folateconjugated nanoparticles show a better cell uptake efficiency than unconjugated nanoparticles. However, after adding free FA to the medium containing FITC-labeled ATO, a lower fluorescence intensity was observed, indicating that free FA prevents ATO from transporting into Hela cells by competitive binding to folate receptors on the cell surface. In addition, A549 cells showed relatively low fluorescence uptake on addition of FITC-labeled ATO. These results indicated that FA-conjugated nanoparticles are a potential drug delivery system that targets tumor cells through folate receptor-mediated endocytosis. 

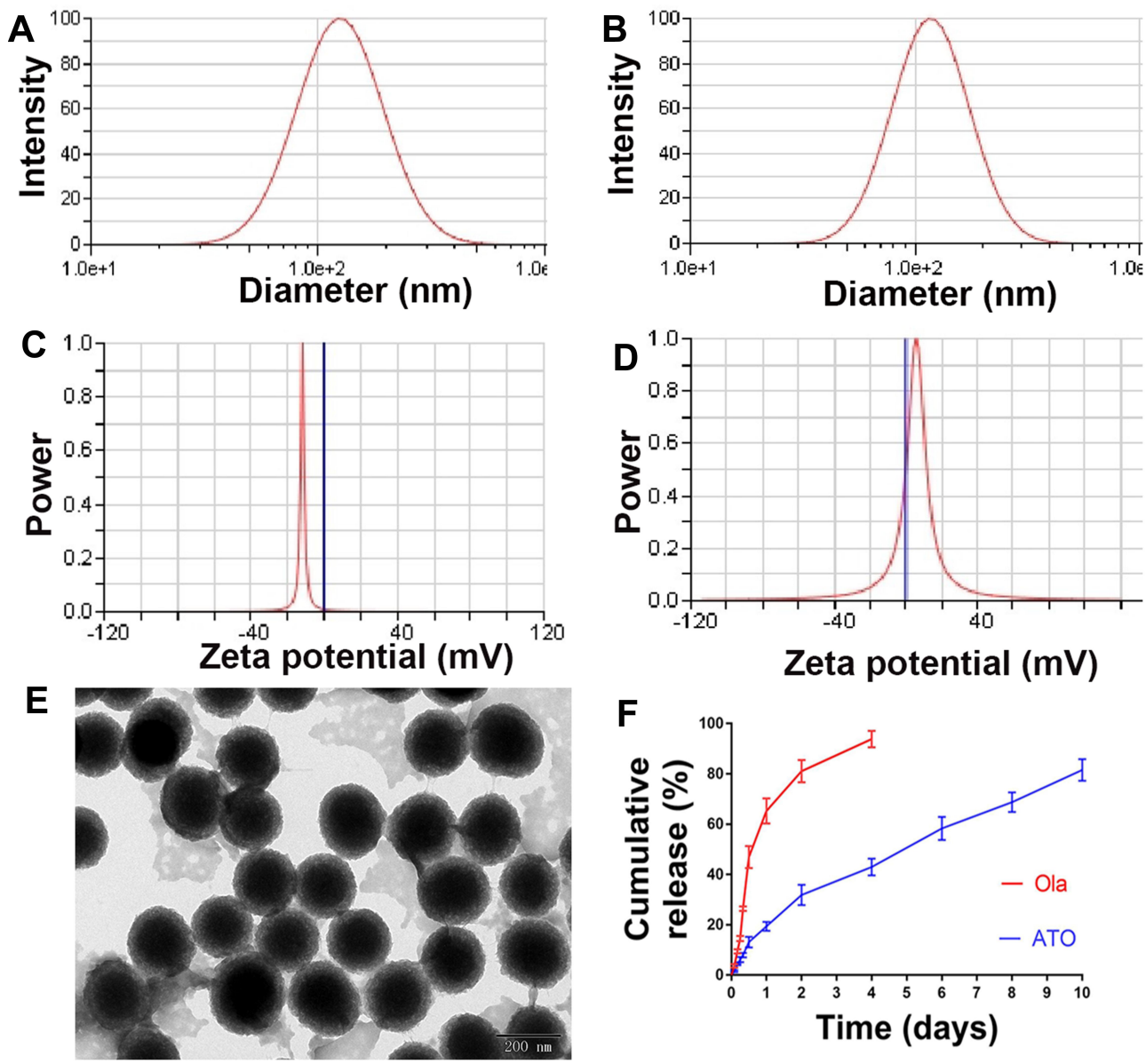

Figure 3 The characterization of ATO. (A) Particle size distribution of ATO, presented a mean size of $240.62 \pm 8.79 \mathrm{~nm}$. (B) Particles size distribution of NATO, presented a mean size of $205.43 \pm 3.13 \mathrm{~nm}$. (C) Zeta potential of ATO, showed a negative surface charge of $-10.5 \pm 1.09 \mathrm{mV}$. (D) Zeta potential of NATO, showed a positive surface charge of $4.67 \pm 1.17 \mathrm{mV}$. (E) Transmission electron microscopy image of ATO (the scale is $50 \mathrm{~nm}$ ). (F) Drug release study of Ola and ATO.

\section{In vivo Anti-Tumor Efficacy of Radiotherapy Combined with ATO}

The therapeutic efficacy of ATO+RT on Hela xenografted mice was assessed as shown in Figure 5. The PET/CT images and tumor appearance in mice in each group are shown in Figure 5A and $\mathrm{B}$. According to the tumor appearance, the tumor volume was the largest in the mice in the Control group, whereas the tumor volume in the mice in the ATO $+\mathrm{RT}$ group was the smallest. Based on the results of PET/CT imaging (Figure 5C), the mean SUVmax of the tumor in each group was observed: $2.73 \pm 0.25$ (control), $2.26 \pm 0.25$ (NATO), $1.77 \pm 0.15$ (ATO), $1.63 \pm 0.25$ (RT), $1.33 \pm 0.15$ (NATO+RT), and $0.93 \pm 0.05$ (ATO+RT). The SUVmax of mice in the ATO+RT group was the lowest when compared to NATO+RT, RT and other groups, indicating that the tumor in this group has the lowest metabolism, and thereby implying a more powerful anti-tumor effect of ATO+RT. In addition, the tumor volume in mice in different groups after treatment was measured and plotted as shown in Figure 5D. Tumor growth was delayed by 3 days in mice treated with NATO alone $(P<$ $0.05)$, whereas the ATO group and RT group showed a delay in tumor growth by 6 and 12 days, respectively $(P<0.05)$. The NATO+RT group showed a tumor growth delay of 18 days and the ATO+RT group exhibited a tumor growth delay of 24 days, which was longer than the other five groups mentioned above. These results indicated that ATO+RT had a more effective synergistic effect in inhibiting tumor growth compared with other therapies. At the same time, a similar effect was observed for the median survival time in mice (Figure $5 \mathrm{E})$. The median survival time of mice in the ATO+RT group (50 days) was significantly longer than that of mice in the NATO+RT (42 days), RT (38 days), ATO (38 days), NATO (34 days) and Control (32 days) groups $(P<0.05)$.

\section{Immunohistochemical Analysis}

The immunohistochemical analysis results are demonstrated in Figure 6A. The results showed that ATO+RT significantly 


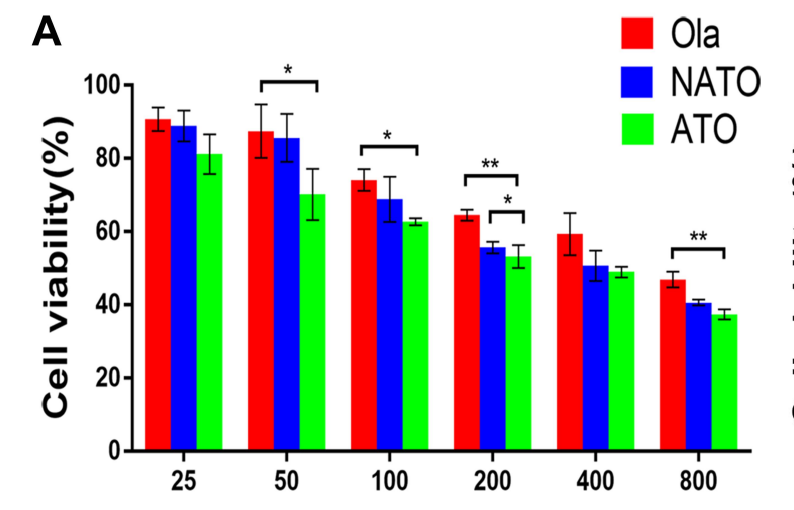

C

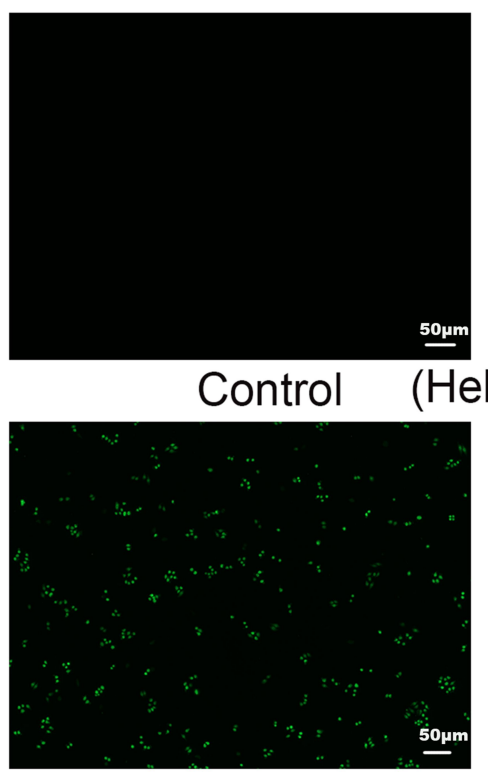

FITC-labeled ATO
B

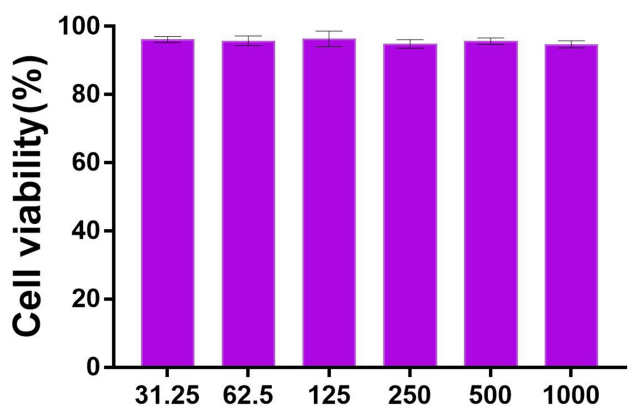

Concentration( $\mu \mathrm{g} / \mathrm{L})$

Figure 4 In vitro cell viability and fluorescent images. (A) Cell viability of free Ola, NATO and ATO on Hela cell after $24 \mathrm{~h}$ incubation. *P<0.05; **P<0.0I; no statistical significance between unlabeled groups. (B) Cell viability of FA-PCEC. (C) Fluorescent images of Hela cells treated with culture medium, FITC-labeled NATO, FITC-labeled ATO and FITC-labeled ATO+FA for $2 \mathrm{~h}$ and fluorescent images of A549 cells treated with FITC-labeled ATO for $2 \mathrm{~h}$.

increased the expression of $\gamma-\mathrm{H} 2 \mathrm{AX}$ and reduced the expression of Ki-67 in mice.

The proportion of $\gamma$-H2AX-positive cells in the ATO+RT group was $76.65 \% \pm 2.88 \%$, which showed an increased apoptotic rate when compared to NATO+RT $(63.8 \% \pm$ $3.77 \%)$, RT $(53.86 \% \pm 3.32 \%)$ and other treatment groups (Figure 6B) $(\mathrm{P}<0.05)$.

$\mathrm{Ki}-67$ is an immune indicator that reflects tumor cell proliferation. The percentage of $\mathrm{Ki}-67$-positive cells in different groups is as follows (Figure 6C): Control group, 84.82\% \pm $2.11 \%$; NATO group, $56.78 \% \pm 1.41 \%$; ATO group, $42.43 \% \pm$ $3.35 \%$; RT group, $41.55 \% \pm 1.95 \%$; and NATO+RT group, $30.4 \% \pm 2.54 \%$. In addition, there was an obvious decrease in the percentage of Ki-67-positive cells in ATO+RT group
$(19.51 \% \pm 3.04 \%)$ compared with that in other groups $(\mathrm{P}<0.01)$.

\section{Flow Cytometry}

Flow cytometry was used to detect the apoptosis levels of tumor tissues in each group (Figure 7A). As shown in Figure 7B, there was no significant difference in apoptosis rate between $\mathrm{ATO}+\mathrm{RT}$ group and $\mathrm{NATO}+\mathrm{RT}$ group $(\mathrm{P}>0.05)$. But the rate of apoptosis in ATO+RT and NATO+RT groups were higher than that in RT $(60.56 \%$ $\pm 4.12 \%)$, ATO $(52.33 \% \pm 3.6 \%)$ and other groups. This result indicated that a combination of ATO or NATO with RT significantly increased the apoptosis rate of tumor cells. 

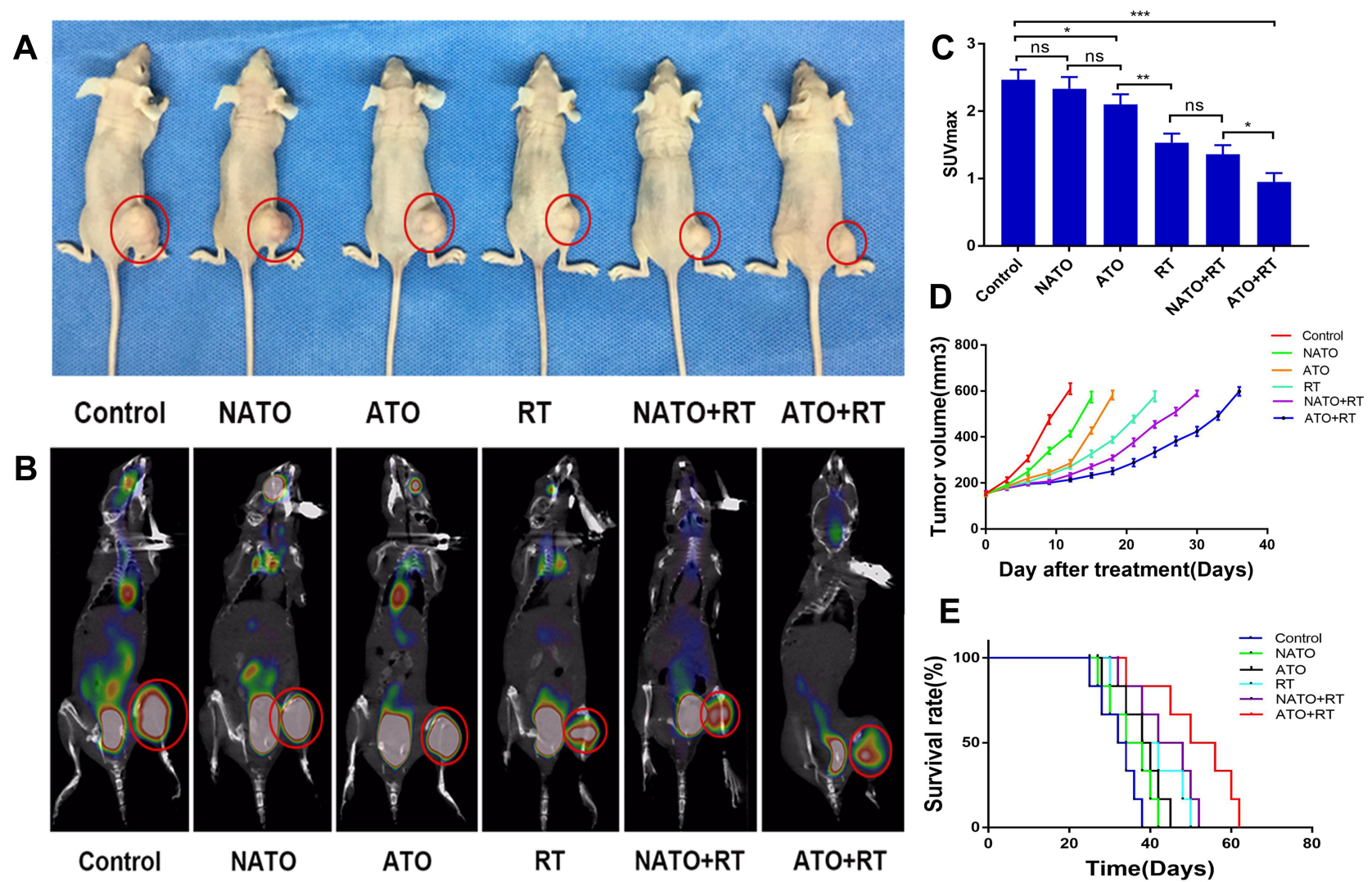

E

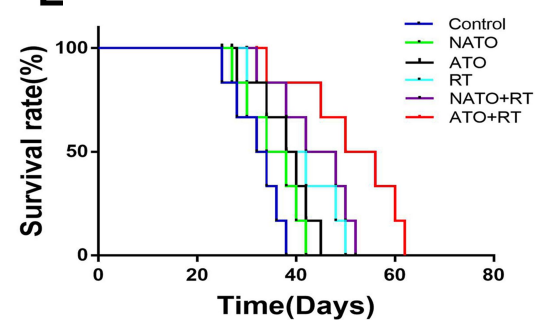

Figure 5 Evaluation of antitumor efficiency in vivo. (A) General view of tumor-bearing example mice with different treatments. (B) PET/CT images of example mice in each group. (C) Quantitative analysis of SUVmax of mice in each group. ${ }^{* P}<0.05$; ${ }^{*} \mathrm{P}<0.0 \mathrm{I}$; ${ }^{* * *} \mathrm{P}<0.00 \mathrm{I}$; ns: no statistical significance. (D) Tumor growth curves of mice in each group. (E) The survival curves of mice in each group.

\section{Evaluation the Side Effects of ATO}

In this experiment, the in vivo toxicity of different treatments was evaluated by observing the pathological changes in important organs of nude mice in each group. After the nude mice were sacrificed, the heart, liver, spleen, lung and kidney of the mice were prepared for H\&E staining. As shown in Figure 8, no obvious pathological changes were found in each treatment group.

\section{Discussion}

Cervical cancer, as a common malignant tumor that seriously threatens women's health, has shown a high incidence in recent years. ${ }^{26} \mathrm{RT}$ is one of the most important treatment options for cervical cancer as it not only improves tumor control but also reduces complications. ${ }^{27,28}$ The mechanism of RT is mainly to cause DNA strand breaks in tumor cells, but the self-repair function of the tumor tissue makes the tumor tissue less sensitive to radiation. Therefore, targeted inhibition of DNA repair to improve the efficacy of RT has become one of the research hotspots in recent years. ${ }^{2}$
PARP is a well-known enzyme closely associated in DNA damage repair. PARP inhibitors can precisely inhibit the activity of PARP and the repair of single-stranded DNA breaks, causing a synthetic lethal effect that leads to the death of tumor cells and enhancing the effect of RT. ${ }^{4}$ Ola is a representative PARP inhibitor, which is approved for use in the treatment of advanced ovarian cancer patients with BRCA1/2 mutation. ${ }^{29}$ Previous studies have confirmed that Ola can be used in combination with RT to enhance its antitumor effects. ${ }^{8,30,31}$ At the same time, our research group has previously confirmed that Ola nanoparticles combined with RT showed enhanced anti-tumor effects on lung cancer A549 xenografts in nude mice at an early stage, ${ }^{17}$ which further improves the feasibility of its clinical promotion. According to research reports, drug-loaded nanoparticles can achieve passive targeting in tumors because of enhanced permeability and retention effect (EPR). ${ }^{32}$ However, only a small fraction of nanoparticles accumulating in solid tumors through passive targeting can be absorbed. ${ }^{33,34}$ Thus, to improve the targeting efficiency, it is necessary to introduce targeting molecules (such as folic acid and monoclonal antibodies) 

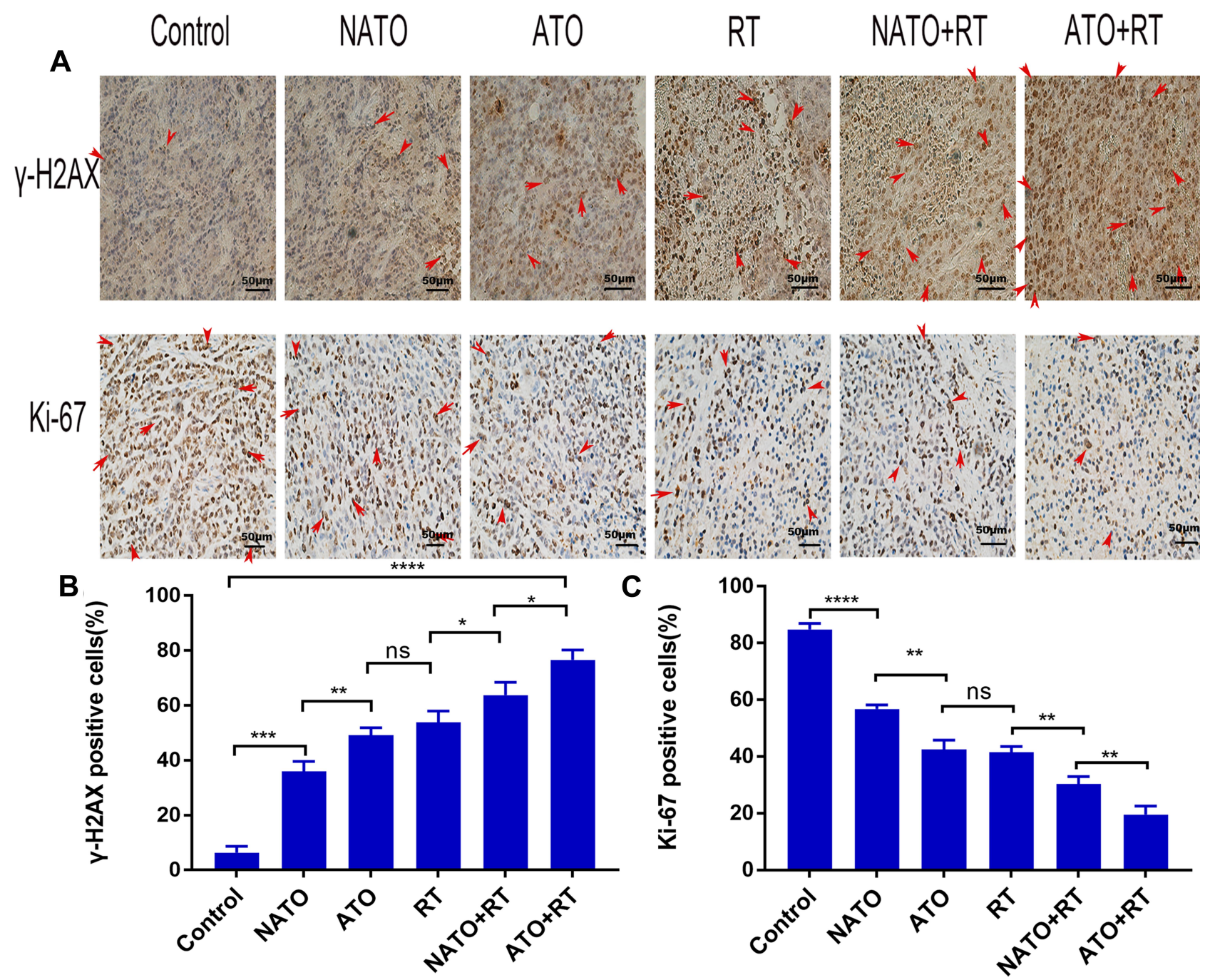

Figure 6 Immunohistochemical analysis. (A) Representative images of $\gamma-\mathrm{H} 2 \mathrm{AX}$ and $\mathrm{Ki}-67$ in each group (magnification, $\times 200$ ). (B) Quantitative analysis of $\gamma-\mathrm{H} 2 \mathrm{AX}$ in each group. (C) Quantitative analysis of $\mathrm{Ki}-67$ in each group. ${ }^{*} \mathrm{P}<0.05$; $* * \mathrm{P}<0.0 \mathrm{I} ;{ }^{*} * \mathrm{P}<0.00 \mathrm{I}$; ${ }^{*} * * * \mathrm{P}<0.000 \mathrm{I}$.

Abbreviation: $n s$, no statistical significance.

that can recognize and bind to specific receptors on cancer cells. ${ }^{35-37}$ Furthermore, a preliminary study by our research group confirmed that folate-conjugated nanoparticles have an active targeting inhibitory effect on tumors rich in folate receptors on their cell surface. ${ }^{18}$ This work reveals that it is possible to target DNA damage to tumor cells and improve the therapeutic effect of RT.

Therefore, this study aimed to prepare ATO and explore the targeted enhancement of therapeutic effect when using ATO in combination with RT. First, an emulsification/solvent diffusion method was used to successfully prepare injectable ATO. Compared with other recently reported nanoparticles, ATO showed a stable particle size and higher DL. ${ }^{38,39}$ In addition, the sustained slow release trend of ATO may be attributed to the relatively stable structure of the folate polymer carrier. The cytotoxicity experiments suggested that ATO lead to decreased cell viability of tumor cells, which was associated with the lack of BRCA2 in cervical cancer cells and is consistent with previous research. ${ }^{40,41}$ However, FAPCEC showed almost no cytotoxic effect. These findings indicated that the inhibitory effect of ATO was attributed to the Ola wrapped in it. In this study, the uptake of folateconjugated nanoparticles by Hela cells was more significant. In addition, a lower fluorescence intensity was observed after adding free folate into the medium. Moreover, a lower fluorescence intensity was observed in A549 cells that are negative for folate receptor; this proves our hypothesis that the active endocytosis of ATO by Hela cells was mediated by folate receptors. Thus, these results 

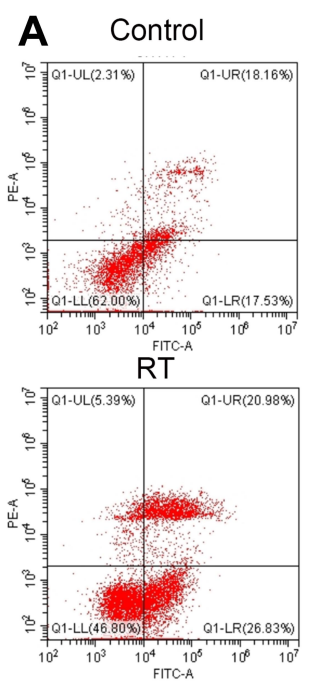
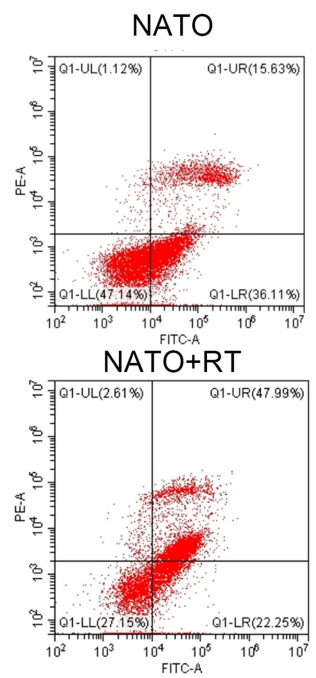

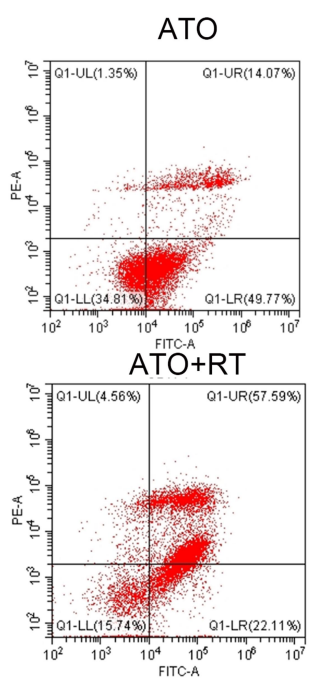

\section{B}

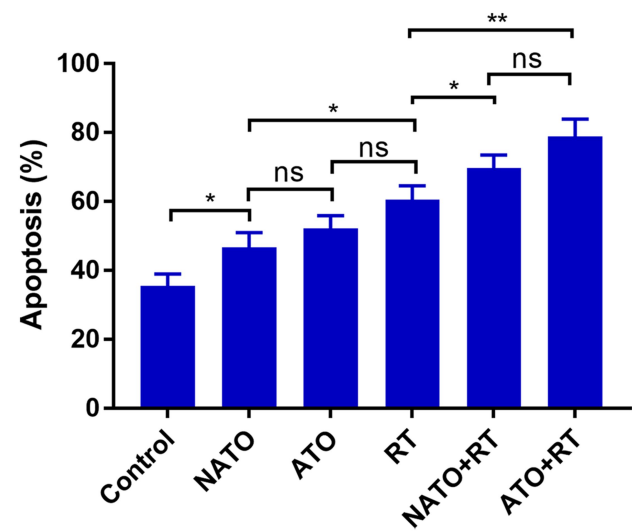

Figure 7 Apoptosis analysis of tumor tissues in each group. (A) Apoptosis graphs of each group. (B) Quantitative analysis of apoptosis. *P<0.05; ** $<<0.01$. Abbreviation: ns, no statistical significance.

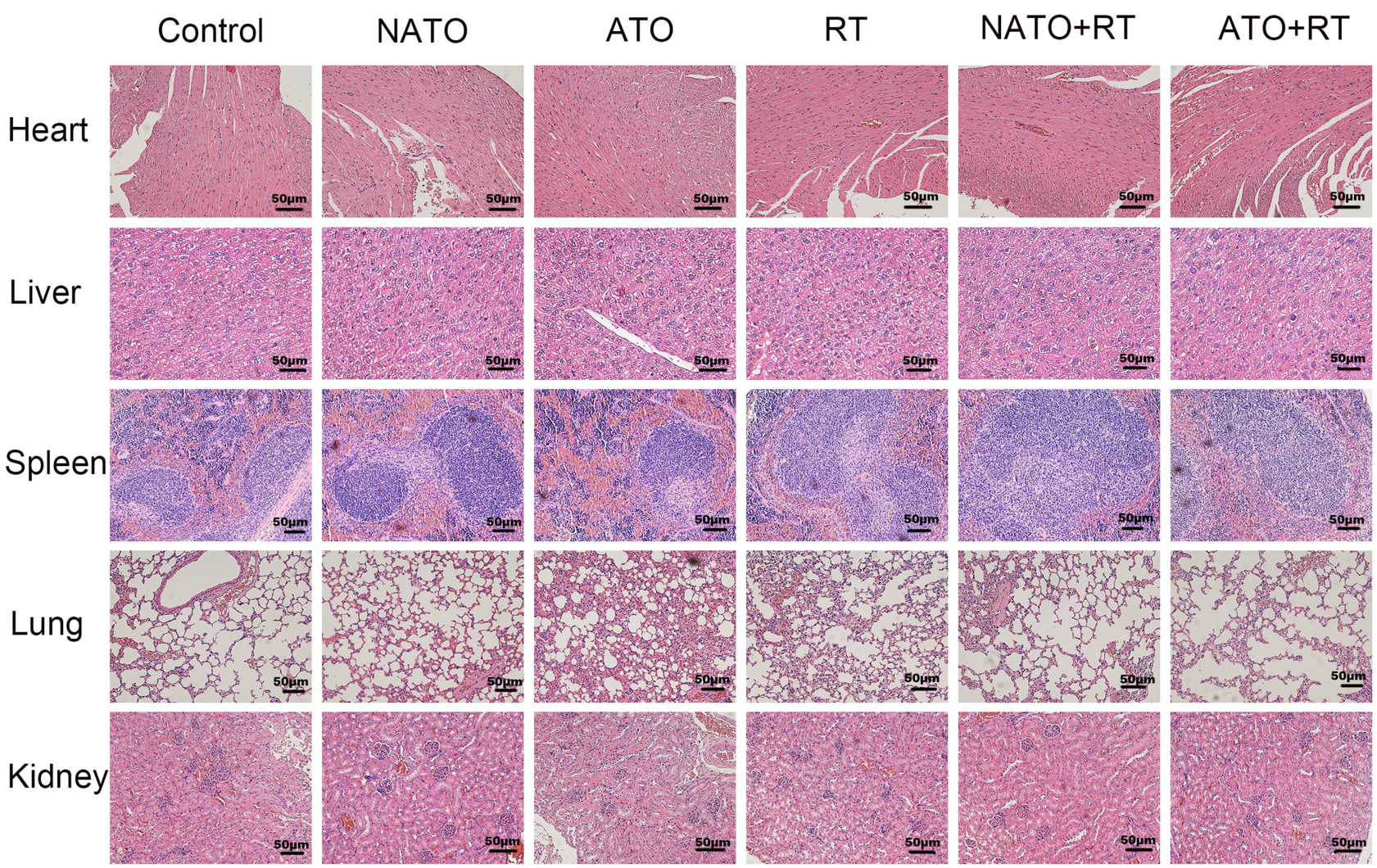

Figure 8 H\&E staining of heart, liver, spleen, lung, and kidney of each group (magnification, $\times 200$ ).

indicated that ATO prominently inhibited cancer cell growth by delivering more Ola into Hela cells by folatemediated endocytosis.

We subsequently established a nude mouse xenograft model using cervical cancer Hela cells to investigate the therapeutic effect of ATO+RT. A RT dose of 10 Gy has always been used in studies reporting combined use of olaparib and RT. ${ }^{5,42,43}$ In our in vivo anti-tumor study, TGD and survival duration of mice treated with ATO+RT were significantly higher than those of mice treated with other treatment 
measures; this further confirmed that ATO combined with RT had a better anti-tumor effect on cervical cancer xenograft model. The abovementioned results are consistent with the results of our previous study concerning the combined use of Ola and RT. ${ }^{17}$ This is probably because of the active targeted uptake of ATO by Hela cells resulting in a high concentration of Ola in the cells, which further results in a more pronounced therapeutic effect when combined with RT. ${ }^{18}$ F-FDG PET/CT was used to understand the early therapeutic effects in nude mice. Previous studies have shown that ${ }^{18}$ F-FDG PET/CT can reflect the level of glucose metabolism, which is closely associated with the therapeutic effect on the tumor. ${ }^{38}$ In tumor tissues, high glucose metabolism indicates a worse therapeutic effect, whereas low glucose metabolism often demonstrates a better therapeutic effect. The mice in the ATO+RT group showed the lowest glucose uptake compared with those in other groups, suggesting that ATO+RT had a better effect of inhibiting tumor growth.

In this study, immunohistochemical analysis was used to detect $\gamma-\mathrm{H} 2 \mathrm{AX}$ and $\mathrm{Ki}-67$ expressions in tumor tissue. The results suggested that mice in the ATO+RT group showed a higher expression level of $\gamma-\mathrm{H} 2 \mathrm{AX}$ than those in other groups. Previous studies have shown that Ola combined with RT can increase DNA double-strand breaks. Therefore, the expression of $\gamma-\mathrm{H} 2 \mathrm{AX}$, a biomarker for DNA double-strand breaks, was detected to confirm the DNA damage in each group. $\mathrm{Ki}-67$ is a tumor proliferation index; our results indicated that the mice in the ATO+RT group had the lowest proportion of Ki-67-positive cells among all groups. These results were similar to those reported in previous studies. ${ }^{2,44}$ The increased expression of $\gamma-\mathrm{H} 2 \mathrm{AX}$ and the decreased expression of $\mathrm{Ki}-67$ in the ATO+RT group may be because of the active targeting uptake of ATO in Hela cells to form high concentrations of Ola in Hela cells. The results of flow cytometry also showed that tumor tissues in ATO+RT group had the highest rate of apoptosis, which is similar to previously reported results. ${ }^{45}$ The increased sensitivity of tumor cells to apoptosis may be associated with the down-regulation of the anti-apoptotic protein. $^{46,47}$

In summary, these results indicate that ATO in combination with RT has a synthetic lethal effect on cervical cancer xenografts. Although the results are encouraging, shortcomings and limitations of our research clearly exist. Therefore, the tissue distribution of nanoparticles in vivo needs to be evaluated further in subsequent experiments. Also, further in vivo studies with folate receptor-negative cell lines should be conducted in the future.

\section{Conclusion}

In this study, ATO was successfully prepared. Data showed that ATO had outstanding targeted effect on cervical cancer xenograft tumor. ATO+RT significantly inhibited the growth of cervical cancer cells and prolonged the median survival duration of mice. In addition, we explored the mechanism of synthetic lethal effect of ATO+RT and found that ATO+RT induces DSBs and increases the apoptosis of tumor cells. In summary, ATO has good application prospects for tumors with an over-expression of folate receptors.

\section{Acknowledgments}

This study was supported by the Major Project of the first Affiliated Hospital of Southwest Medical University, project number P2017001.

\section{Disclosure}

The authors report no conflicts of interest in this work.

\section{References}

1. Zuckerman AJ. IARC monographs on the evaluation of carcinogenic risks to humans. J Clin Pathol. 1995;48(7):691-a. doi:10.1136/ jcp.48.7.691-a

2. Annika K, Kerstin C, Kerstin B, et al. Inhibition of PARP1-dependent end-joining contributes to Olaparib-mediated radiosensitization in tumor cells. Mol Oncol. 2014;8(16):16-25.

3. Verhagen Caroline VM, de Haan R, Floor H, et al. Extent of radiosensitization by the PARP inhibitor olaparib depends on its dose, the radiation dose and the integrity of the homologous recombination pathway of tumor cells. Radiother Oncol. 2015;116(3):58-65.

4. Albert JM, Cao C, Kim KW, et al. Inhibition of poly (ADP-Ribose) polymerase enhances cell death and improves tumor growth delay in irradiated lung cancer models. Clin Cancer Res. 2007;13(10):33-42. doi:10.1158/1078-0432.CCR-06-2872

5. Yanyan J, Tom V, Devery Aoife M, et al. Hypoxia potentiates the radiation-sensitizing effect of olaparib in human non-small cell lung cancer xenografts by contextual synthetic lethality. Int $J$ Radiat Oncol Biol Phys. 2016;95(7):72-81.

6. Gelmon KA, Tischkowitz M, Mackay H, et al. Olaparib in patients with recurrent high-grade serous or poorly differentiated ovarian carcinoma or triple-negative breast cancer: a phase 2, multicentre, open-label, non-randomised study. Lancet Oncol. 2011;12(9):52-61. doi:10.1016/S1470-2045(11)70214-5

7. Wang W, Duan B, Zeng L, et al. Effect and mechanism of radiosensitization of poly (ADP-Ribose) polymerase inhibitor on lewis cells and xenografts. Chin J Lung Cancer. 2016;19(1):16-23.

8. Senra Joana M, Telfer Brian A, Cherry Kim E, et al. Inhibition of PARP-1 by olaparib (AZD2281) increases the radiosensitivity of a lung tumor xenograft. Mol Cancer Ther. 2011;10(19):49-58.

9. Liu JF, Barry WT, Birrer M, et al. Combination cediranib and olaparib versus olaparib alone for women with recurrent platinum-sensitive ovarian cancer: a randomised phase 2 study. Lancet Oncol. 2014;15(11):07-14. doi:10.1016/S1470-2045(14) 70391-2

10. Yu X, Guoyi T, Changbing W, et al. Functionalized selenium nanoparticles for targeted siRNA delivery silence Derlin1 and promote antitumor efficacy against cervical cancer. Drug Deliv. 2020;27 (1):15-25. doi:10.1080/10717544.2019.1667452 
11. Yu X, Misi X, Mingqi Z, et al. Doxorubicin-loaded functionalized selenium nanoparticles for enhanced antitumor efficacy in cervical carcinoma therapy. Mater Sci Eng C Mater Biol Appl. 2020;106:110100. doi:10.1016/j.msec.2019.110100

12. Eugenia T, Catalin Z, Ariana H, et al. Impact of the magnetic field on 3T3-E1 preosteoblasts inside SMART silk fibroin-based scaffolds decorated with magnetic nanoparticles. Mater Sci Eng C Mater Biol Appl. 2020;110:110714. doi:10.1016/j.msec.2020.110714

13. Huang Y, Yang T, Zhang W, et al. A novel hydrolysis-resistant lipophilic folate derivative enables stable delivery of targeted liposomes in vivo. Int J Nanomedicine. 2014;9(45):81-95.

14. Xie M, Zhang $\mathrm{H}, \mathrm{Xu} \mathrm{Y}$, et al. Expression of folate receptors in nasopharyngeal and laryngeal carcinoma and folate receptor-mediated endocytosis by molecular targeted nanomedicine. Int J Nanomedicine. 2013;8(24):43-51.

15. Batoul F, Carvalho MR, Prameswari K, et al. Folate-conjugated nanovehicles: strategies for cancer therapy. Mater Sci Eng C Mater Biol Appl. 2020;107(110):03-41.

16. Xue H, Jing L, Min L, et al. 9-NC-loaded folate-conjugated polymer micelles as tumor targeted drug delivery system: preparation and evaluation in vitro. Int J Pharm. 2009;372(1):25-31.

17. Min W, Jing L, ChuanFei H, et al. Olaparib nanoparticles potentiated radiosensitization effects on lung cancer. Int $J$ Nanomedicine. 2018;13(82):61-72.

18. Bo Y, XiaoLing N, LongXia C, et al. Honokiol-loaded polymeric nanoparticles: an active targeting drug delivery system for the treatment of nasopharyngeal carcinoma. Drug Deliv. 2017;24(6):60-69.

19. MaLing G, ChangYang G, Juan Z, et al. Polymeric matrix for drug delivery: honokiol-loaded PCL-PEG-PCL nanoparticles in PEG-PCL-PEG thermosensitive hydrogel. J Biomed Mater Res A. 2010;93(2):19-26.

20. Liu P, Yu H, Sun Y, et al. A mPEG-PLGA-b-PLL copolymer carrier for adriamycin and siRNA delivery. Biomaterials. 2012;33 (17):4403-4412. doi:10.1016/j.biomaterials.2012.02.041

21. Zelai HJ. Co-delivery of cisplatin and paclitaxel by folic acid conjugated amphiphilic PEG-PLGA copolymer nanoparticles for the treatment of non-small lung cancer. Oncotarget. 2015;6(421):50-68.

22. Farnaz E, Hossein GM, Nasser OS, et al. Folate-receptor-targeted delivery of docetaxel nanoparticles prepared by PLGA-PEG-folate conjugate. J Drug Target. 2008;16(4):15-23.

23. Fasehee H, Dinarvand R, Ghavamzadeh A, et al. Delivery of disulfiram into breast cancer cells using folate-receptor-targeted PLGA-PEG nanoparticles: in vitro and in vivo investigations. J Nanobiotechnology. 2016;14(1):32. doi:10.1186/s12951-016-0183-z

24. XiuLing Z, Bing $\mathrm{K}$, MaLing G, et al. Preparation of MPEG-PLA nanoparticle for honokiol delivery in vitro. Int J Pharm. 2010;386 (26):2-7.

25. Zhou YY, Du YZ, Wang L, et al. Preparation and pharmacodynamics of stearic acid and poly (lactic-co-glycolic acid) grafted chitosan oligosaccharide micelles for 10-hydroxycamptothecin. Int J Pharm. 2010;393(1-2):144-152. doi:10.1016/j.ijpharm.2010.04.025

26. Avinash B, Parshuram RV, Kirti S, et al. Prospective evaluation of the setup errors and its impact on safety margin for cervical cancer pelvic conformal radiotherapy. Rep Pract Oncol Radiother. 2020;25 (2):60-65.

27. Vicharn L, Imjai C, Supatra S, et al. Concurrent mitomycin C, 5-fluorouracil, and radiotherapy in the treatment of locally advanced carcinoma of the cervix: a randomized trial. Int J Radiat Oncol Biol Phys. 2003;55(12):26-32.

28. Paulina C, Ewa B, Ewa W, et al. The effect of different segmentation methods on primary tumour metabolic volume assessed in F-FDG$\mathrm{PET} / \mathrm{CT}$ in patients with cervical cancer, for radiotherapy planning. Contemp Oncol (Pozn). 2019;23(3):183-186.

29. Zimmer AS, Gillard M, Lipkowitz S, et al. Update on PARP inhibitors in breast cancer. Curr Treat Options Oncol. 2018;19(5):21-28. doi:10.1007/s11864-018-0540-2
30. Güster JD, Weissleder SV, Busch CJ, et al. The inhibition of PARP but not EGFR results in the radiosensitization of HPV/p16-positive HNSCC cell lines. Radiother Oncol. 2014;113(3):345-351. doi:10.1016/j.radonc.2014.10.011

31. Polly G, James N, Emma G, et al. Radiosensitization with an inhibitor of poly (ADP-ribose) glycohydrolase: a comparison with the PARP1/2/3 inhibitor olaparib. DNA Repair (Amst). 2018;6(1):25-36.

32. Karel U, Vladimír S. Polymeric anticancer drugs with $\mathrm{pH}$-controlled activation. Adv Drug Deliv Rev. 2004;56(10):23-50.

33. Brigger I, Dubernet C, Couvreur P. Nanoparticles in cancer therapy. Adv Drug Deliv Rev. 2002;54(5):631-651. doi:10.1016/S0169-409X (02)00044-3

34. Choi KY, Chung H, Min KH, et al. Self-assembled hyaluronic acid nanoparticles for active tumor targeting. Biomaterials. 2010;31 (1):106-114. doi:10.1016/j.biomaterials.2009.09.030

35. Prabaharan M, Grailer JJ, Pilla S, Steeber DA, Gong S. Gold nanoparticles with a monolayer of doxorubicin-conjugated amphiphilic block copolymer for tumor-targeted drug delivery. Biomaterials. 2009;30(60):65-75.

36. Lin JJ, Chen JS, Huang SJ, et al. Folic acid-Pluronic F127 magnetic nanoparticle clusters for combined targeting, diagnosis, and therapy applications. Biomaterials. 2009;30(51):14-24. doi:10.1016/j. biomaterials.2009.06.004

37. Peifeng L, Zonghai L, Mingjie Z, et al. Preparation of EGFR monoclonal antibody conjugated nanoparticles and targeting to hepatocellular carcinoma. J Mater Sci Mater Med. 2010;21(55):1-6.

38. YanXin Y, Shan X, Hong Y, et al. In vivo synergistic anti-tumor effect of paclitaxel nanoparticles combined with radiotherapy on human cervical carcinoma. Drug Deliv. 2017;24(1):75-82. doi:10.1080/10717544.2016.1230902

39. Wang $\mathrm{Y}, \mathrm{Wu} \mathrm{M}, \mathrm{Gu} \mathrm{L}$, et al. Effective improvement of the neuroprotective activity after spinal cord injury by synergistic effect of glucocorticoid with biodegradable amphipathic nanomicelles. Drug Deliv. 2017;24(1):391-401. doi:10.1080/ 10717544.2016.1256003

40. Gopeshwar N, Hugo AP, Nandula Subhadra V, et al. Promoter hypermethylation of FANCF: disruption of Fanconi Anemia-BRCA pathway in cervical cancer. Cancer Res. 2004;64:24-28.

41. Anna B, Salvatore L, Gary A, et al. PARP-1 activity (PAR) determines the sensitivity of cervical cancer to olaparib. Gynecol Oncol. 2019;155:144-150. doi:10.1016/j.ygyno.2019.08.010

42. van de Ven Anne L, Shifalika T, Paige B, et al. PTEN/TP53nanoformulation of olaparib amplifies PARP inhibition and sensitizes deficient prostate cancer to radiation. Mol Cancer Ther. 2017;16 (12):79-89.

43. Eiko N. C225 antiepidermal growth factor receptor antibody enhances the efficacy of docetaxel chemoradiotherapy. Int $J$ Radiat Oncol Biol Phys. 2004;59(11):63-73.

44. Cui Y, Zhang C, Li X, et al. Intravoxel incoherent motion diffusion-weighted magnetic resonance imaging for monitoring the early response to ZD6474 from nasopharyngeal carcinoma in nude mouse. Sci Rep. 2015;5(1):63-89. doi:10.1038/srep16389

45. Hongju P, Huang Q, Hongcheng Y, et al. The antitumor effect of cisplatin-loaded thermosensitive chitosan hydrogel combined with radiotherapy on nasopharyngeal carcinoma. Int J Pharm. 2019;55 (6):97-105.

46. Deben C, Lardon F, Wouters A, et al. APR-246 (PRIMA-1MET) strongly synergizes with AZD2281 (olaparib) induced PARP inhibition to induce apoptosis in non-small cell lung cancer cell lines. Cancer Lett. 2016;375(2):313-322. doi:10.1016/j. canlet.2016.03.017

47. Kumar CG, Poornachandra Y, Chandrasekhar C. Green synthesis of bacterial mediated anti-proliferative gold nanoparticles: inducing mitotic arrest (G2/M phase) and apoptosis (intrinsic pathway). Nanoscale. 2015;7(44):18738-18750. doi:10.1039/ C5NR04577K 


\section{Publish your work in this journal}

The International Journal of Nanomedicine is an international, peerreviewed journal focusing on the application of nanotechnology in diagnostics, therapeutics, and drug delivery systems throughout the biomedical field. This journal is indexed on PubMed Central, MedLine, CAS, SciSearch ${ }^{\circledR}$, Current Contents ${ }^{\circledR} /$ Clinical Medicine,
Journal Citation Reports/Science Edition, EMBase, Scopus and the Elsevier Bibliographic databases. The manuscript management system is completely online and includes a very quick and fair peer-review system, which is all easy to use. Visit http://www.dovepress.com testimonials.php to read real quotes from published authors. 